2020-03

\title{
Offshore conversion of wind power to gaseous fuels: Feasibility study in a depleted gas field
}

\author{
O'Kelly-Lynch, PD
}

http://hdl.handle.net/10026.1/17667

\subsection{7/0957650919851001}

Proceedings of the Institution of Mechanical Engineers, Part A: Journal of Power and Energy SAGE Publications

All content in PEARL is protected by copyright law. Author manuscripts are made available in accordance with publisher policies. Please cite only the published version using the details provided on the item record or document. In the absence of an open licence (e.g. Creative Commons), permissions for further reuse of content should be sought from the publisher or author. 


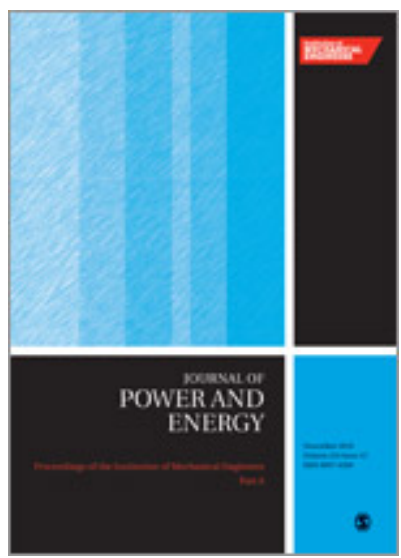

\section{Offshore Conversion of Wind Power to Gaseous Fuels: Feasibility Study in a Depleted Gas Field}

\begin{tabular}{|c|c|}
\hline Journal: & Part A: Journal of Power and Energy \\
\hline Manuscript ID & JPE-17-0359.R2 \\
\hline Manuscript Type: & Original Article \\
\hline $\begin{array}{r}\text { Date Submitted by the } \\
\text { Author: }\end{array}$ & 20-Oct-2018 \\
\hline Complete List of Authors: & $\begin{array}{l}\text { O'Kelly Lynch, Patrick; School of Engineering; Marine Renewable Energy } \\
\text { Ireland Research Centre; co-lead author } \\
\text { Gallagher, Paul; School of Engineering; Marine Renewable Energy } \\
\text { Ireland Research Centre } \\
\text { Borthwick, Alistair; University of Edinburgh, Institute of Energy Systems } \\
\text { McKeogh, Eamon; School of Engineering; Marine Renewable Energy } \\
\text { Ireland Research Centre } \\
\text { Leahy, Paul; School of Engineering; Marine Renewable Energy Ireland } \\
\text { Research Centre }\end{array}$ \\
\hline Keywords: & $\begin{array}{l}\text { Energy storage/ auxiliary systems, Offshore wind farms, Wind power } \\
\text { utilisation, Carbon dioxide, Carbon capture and sequestration, Wind } \\
\text { energy systems, Energy conversion/ recovery }\end{array}$ \\
\hline Abstract: & $\begin{array}{l}\text { A proof-of-concept study is presented of a Power-to-Gas (PtG) system } \\
\text { that is located fully offshore. This paper analyses how such a system } \\
\text { would perform if based at the depleted Kinsale Gas Field in the Celtic Sea } \\
\text { Basin off the south coast of Ireland. An offshore wind farm is proposed } \\
\text { as the power source for the system. Several conversion technologies are } \\
\text { examined in detail in terms of resource efficiency, technological } \\
\text { maturity, and platform area footprint, the aim being to ascertain their } \\
\text { overall applicability to an offshore PtG system. The technologies include } \\
\text { proton exchange membrane electrolysis converters (PEMECS) for } \\
\text { electrolysis of water to release } \mathrm{H}_{2} \text {. Bipolar membrane electro-dialysis } \\
\text { (BPMED) and electronic cation exchange modules (ECEM) processes are } \\
\text { also considered for the extraction of } \mathrm{CO}_{2} \text { from seawater. These } \\
\text { technologies provide the feed-stock for the Sabatier process for the } \\
\text { production of } \mathrm{CH}_{4} \text { from } \mathrm{H}_{2} \text { and } \mathrm{CO}_{2} \text {. Simulations of the end-to-end }\end{array}$ \\
\hline
\end{tabular}


systems were carried out using Simulink, and it was found that the conversion of offshore wind power to hydrogen or methane is a technically feasible option. Hydrogen production is much closer to market viability than methane production, but production costs are too high and conversion efficiencies too low in both cases with present-day technology to be competitive with current wholesale natural gas prices.

\section{SCHOLARONE ${ }^{\text {m }}$ Manuscripts}


Corresponding Author:

Paul D. Gallagher, MaREI Centre, Environmental Research Institute, Beaufort Building, Haulbowline Road, Ringaskiddy, Co. Cork, Ireland.

Email: p.gallagher@ucc.ie

\section{Offshore Conversion of Wind Power to Gaseous Fuels: Feasibility Study in a Depleted Gas Field}

P.D. O'Kelly-Lynch*a,b, P.D. Gallagher* a,b, A.G.L. Borthwick ${ }^{c}$, E.J. McKeogh a,b, P.G. Leahy a,b

${ }^{a}$ MaREI Centre for Marine and Renewable Energy, Environmental Research Institute, University College Cork, Cork, Ireland

${ }^{\mathrm{b}}$ Department of Civil, Structural and Environmental Engineering, School of Engineering, University College Cork, Cork, Ireland

c Institute of Energy Systems, School of Engineering, The University of Edinburgh, The King's Buildings, Edinburgh EH9 3JL, U.K.

* co-lead authors, both authors made equal contributions 


\begin{abstract}
A proof-of-concept study is presented of a Power-to-Gas (PtG) system that is located fully offshore. This paper analyses how such a system would perform if based at the depleted Kinsale Gas Field in the Celtic Sea Basin off the south coast of Ireland. An offshore wind farm is proposed as the power source for the system. Several conversion technologies are examined in detail in terms of resource efficiency, technological maturity, and platform area footprint, the aim being to ascertain their overall applicability to an offshore PtG system. The technologies include proton exchange membrane electrolysis converters (PEMECs) for electrolysis of water to release $\mathrm{H}_{2}$. Bipolar membrane electro-dialysis (BPMED) and electronic cation exchange modules (ECEM) processes are also considered for the extraction of $\mathrm{CO}_{2}$ from seawater. These technologies provide the feedstock for the Sabatier process for the production of $\mathrm{CH}_{4}$ from $\mathrm{H}_{2}$ and $\mathrm{CO}_{2}$. Simulations of the end-to-end systems were carried out using Simulink, and it was found that the conversion of offshore wind power to hydrogen or methane is a technically feasible option. Hydrogen production is much closer to market viability than methane production, but production costs are too high and conversion efficiencies too low in both cases with present-day technology to be competitive with current wholesale natural gas prices.
\end{abstract}

Keywords: Energy storage, electrolysis, Sabatier process, Methanation, Syngas, $\mathrm{CO}_{2}$ extraction from seawater 


\section{Introduction}

This paper addresses three interconnected issues: the re-use of end-of-life oil and gas platforms, carbon dioxide capture and re-use, and the storage of marine renewable energy. By 2010, at least 7,668 offshore platforms had been installed in ocean waters worldwide [1], where on average each platform represents 1,000-20,000 tonnes of steel [2]. As these structures come to the end of their design lives and offshore hydrocarbon fields cease to be exploited, many offshore platforms are being decommissioned, even abandoned. For example, Zawawi et al. [2] have reported that $48 \%$ of platforms in Malaysian waters alone have exceeded their expected 25-year lifetime. The European Commission Directive 2008/98/EC on waste outlines the following hierarchy; Prevention, Re-use, Recycling, Recovery, Disposal [3]. While recycling steel is of legitimate benefit (Zawawi et al. [2] estimate that the 475 megatonnes of steel recycled in 2008 would mitigate 811 megatonnes in $\mathrm{CO}_{2}$ emissions in producing hot rolled steel), re-use is clearly preferable. Repurposing these platforms for ocean colonisation has been suggested; rigs-to-reef programmes exist for platforms in shallow waters in order to enhance offshore habitats, but are ill-suited to deeper waters [4] and provoke strong opposition from environmentalists [2]. It is therefore opportune to ask whether such platforms could be reutilised as part of a more sustainable energy future.

Anthropogenic $\mathrm{CO}_{2}$ emissions are a continuing global concern. The Intergovernmental Panel on Climate Change (IPCC) has recommended that such emissions be cut by $30-85 \%$ by 2050 so as to return the $\mathrm{CO}_{2}$ concentration within the atmosphere to $350-440 \mathrm{ppm}$ [5]. To achieve this, it may also prove necessary to remove excess $\mathrm{CO}_{2}$ already absorbed by the terrestrial and marine 
environment [6]. Doney et al. [7] suggest that about one-third of anthropogenic carbon released to the atmosphere later becomes dissolved in the ocean - this is a mitigating factor for climate change to an extent, but causes ocean $\mathrm{pH}$ levels to drop, and the fundamental chemical balance to alter, leading to ocean acidification (termed "the other $\mathrm{CO}_{2}$ problem").

Global incentives to develop clean, renewable energy sources, have given rise to the concept of Power-to-Gas (PtG), which involves conversion of electricity, typically harnessed from a renewable source, to a gaseous energy carrier such as hydrogen or methane. Where methane is the desired end product, the opportunity for $\mathrm{CO}_{2}$ removal presents itself, such as the PtG process proposed in this paper which utilises $\mathrm{CO}_{2}$ taken from directly from the ocean. Thus, this paper investigates the possibility of implementing an offshore PtG system operating exclusively on renewable resources at an existing gas platform. The system will allow for the re-use of end of life gas infrastructure and provide a means of converting variable offshore wind power into an always-available energy format.

\subsection{Power-to-Gas}

$\mathrm{PtG}$ is the functional description given to the conversion of electrical power into a gaseous energy carrier. The drive towards making PtG a feasible option in the global energy mix is in many ways linked to currently perceived shortcomings of the renewable energy sector. Intermittency of supply and curtailment due to mismatch with demand and grid limitations adversely affect the consistency of renewable energy sources such as wind [8]. This fluctuating curtailed energy can be stored by converting the electricity generated into hydrogen or methane. The stored energy can be reconverted to electricity when required through standard power 
generation, or the gas can be used directly for heating or transport. Where the desired end product is methane, both hydrogen and carbon dioxide need to be sourced.

The increasing proportion of electricity derived from fluctuating, non-synchronous generation sources such as wind turbines is forcing grid operators to curtail output of wind farms at certain times. It has been estimated that in the absence of mitigation measures up to $7 \%$ of wind energy production in Ireland would have been curtailed by 2020 [9]. Previous studies have shown the potential of using wind-generated electricity that would otherwise be curtailed to generate hydrogen to upgrade biogas derived from anaerobic digestion reactors [10]. The production of hydrogen and methane in a PtG system is described in Sections 1.2 and 1.3.

\subsection{Hydrogen Production}

One prospect of a sustainable future is offered by the so-called 'hydrogen economy' based upon the simple chemical reaction between hydrogen and oxygen molecules whereby heat and electric energy (in a fuel cell) are released and water is the sole by-product. It has been estimated that $1 \mathrm{~kg}$ of hydrogen is the equivalent of one US gallon of gasoline with regard to energy provided [11]. However, molecular hydrogen is not abundant in the atmosphere, with a concentration of only $0.00005 \%$ in air; instead, hydrogen is normally bound into more complex molecules such as water and hydrocarbons. Although hydrogen could be extracted from hydrocarbon compounds using fuel-processing technologies, such technologies are non-sustainable due to the use of fossil fuels during processing. An alternative technology for hydrogen production is water electrolysis, which uses electricity to split water into hydrogen and oxygen. Given the availability of renewable electricity, electrolysis has been identified [12] as a key component for PtG. 
Electrolysis essentially involves application of direct electric current to water, to split it into its constituent components hydrogen and oxygen [13]. As of 2013, electrolysis provided $\sim 4 \%$ of global hydrogen demand [14]. The overall chemical reaction during electrolysis is as follows:

$$
2 \mathrm{H}_{2} \mathrm{O}(\mathrm{l}) \rightarrow 2 \mathrm{H}_{2}(g)+\mathrm{O}_{2}(g)
$$

Alkaline Electrolysis Converters (AECs), Solid Oxide Electrolysis Cells (SOECs), and Proton Exchange Membrane Electrolysis Converters (PEMECs) are three examples of electrolysis technologies. SOECs are still in the development stage, whereas AECs previously appeared to have been limited in their applicability to PtG systems owing to their reportedly slow cold-start deployment time, which could impact on their ability to handle fluctuating electricity supplies (typical of renewables such as wind, wave or photovoltaics). However, Grond et al. [13] report that this shortcoming is merely a result of lack of demand for flexible operation, and AECs are fully capable of flexible operation with ramp-up times of seconds over a power load range of 5$100 \%$. The largest onshore PtG plant to date, developed by ETOGAS for Audi AG, has a 6.3 $\mathrm{MW}_{\mathrm{el}}$ capacity and utilizes high-pressure AECs with an electrical load range of $10-110 \%$, and a ramp-up rate of $15 \%$ per second, and $0-100 \%$ per five minutes [14]. It should be noted that the corrosive nature of the alkaline electrolyte used in AECs has led to concerns regarding sustainability issues [13]. The third technology, PEMEC, utilises very thin ( $\mu \mathrm{m}$-scale) proton conductive polymer electrolyte, which facilitates rapid response times to intermittent energy sources such as renewables. PEMECs have efficiencies similar to those of AEC's of $67-82 \%$ and it is expected that PEMFC efficiencies will improve in the coming years [13]. ITM Power and Shell have recently announced the planned installation of a 10 MW PEM electrolyser at Shell's 
Rhineland refinery plant, and to use the hydrogen produced on site by electrolysis for hydrocracking fossil fuel processing on site as well as the provision of grid services. Further details on each of the foregoing electrolysis processes are given in [13]. PEMECs with their perceived good efficiencies, wide range of operating current, modularity and flexible operation abilities were selected for the PtG systems considered herein.

The feed-water used in electrolysis must be of high purity, and satisfy a maximum allowable limit of $0.5 \mathrm{ppm}$ total dissolved solids (TDS) [15], whereas seawater in the Atlantic Ocean has a TDS concentration of 38,500 - 40,000 ppm [16]. Reverse osmosis (RO) and deionisation post treatment are pre-requisites for seawater electrolysis systems in order to achieve required water conditions (American Society for Testing and Materials (ASTM) Type II). Pre-treated seawater is pumped at high pressure into the RO module. A series of semi-permeable, thin-film composite membranes then separates the stream into pure water permeate and a salt-retaining concentrate. Osmotic pressure is the absolute minimum pressure required for the system to operate at its thermodynamic limit [17]. Typical purified water production rates are $45 \%$ for a single pass, and can be theoretically increased to $85-90 \%$ by introduction of a second pass. However, due to osmotic pressure limitations, realistic purified water extraction is capped at about $60 \%$ [18].

\section{3. $\mathrm{CO}_{2}$ Extraction and Renewable Methane Production}

The source of the carbon dioxide is a major factor in the process of renewable methane production as is the energy required to capture and deliver the carbon dioxide to the methanation unit. For a proposed offshore PtG platform, one approach is to utilize existing adjacent resources in order to offset the increased risk and cost incurred because of location in the marine 
environment, noting that the ocean has $\mathrm{a} \mathrm{CO}_{2}$ concentration about 175 times that of air [19]. Several candidate processes are presently under consideration. One involves extracting carbon dioxide from seawater using bipolar membrane electro-dialysis (BPMED), which has reportedly a total $\mathrm{CO}_{2}$ recovery efficiency of 59\% [20]. Another alternative under development by the U.S. Naval Research Laboratory (NRL) comprises a novel three-chambered electronic cation exchange module (ECEM) approach which has been demonstrated in a marine environment at a small scale (1900ml/min seawater feed-rate). One advantage of ECEM over the BPMED process is the simultaneous production of both carbon dioxide and hydrogen, should methane be the desired end-product. The ECEM process consists of influent seawater being acidified by the strong exchange of cations in the electrode compartment, thus aiding the extraction of $\mathrm{CO}_{2}$ bound as carbonate and bicarbonate. Laboratory tests conducted by the U.S. Naval Research Laboratory indicate a total extraction rate of $92 \%$ from natural seawater at $\mathrm{pH} \leq 4$ [19]. Reported production rates of $\mathrm{CO}_{2}$ and $\mathrm{H}_{2}$ are $0.003-0.004 \mathrm{~mol} / \mathrm{min}$ and $0.0093 \mathrm{~mol} / \mathrm{min}$, respectively, for a flow rate of $1900 \mathrm{ml} / \mathrm{min}$ of seawater [19]. Further supplies of $\mathrm{H}_{2}$ would be required to satisfy the methanation process as per the Sabatier Equation used in this study, which requires four times more hydrogen than carbon dioxide:

$$
\mathrm{CO}_{2}+4 \mathrm{H}_{2} \rightarrow \mathrm{CH}_{4}+2 \mathrm{H}_{2} \mathrm{O}
$$

The ratio of hydrogen to carbon dioxide produced by the ECEM would also be suitable for methanol production which requires three times more $\mathrm{H}_{2}$ than $\mathrm{CO}_{2}$. This is another promising energy transformation but is not dealt with in this study. The capturing and storing of the 
additional $\mathrm{CO}_{2}$ produced by the ECEM above what is required for the Sabatier methanation process has been investigated in this study.

The NRL research to date has focused on the development of the ECEM at proof-of-concept level through modifying an off-the-shelf electro-deionisation unit to function as an ECEM. Willauer et al. [19] state that no attempt was made to make the ECEM (585 $\mathrm{kWh} / \mathrm{kg} \mathrm{H}_{2}$ at STP) as energy efficient as a typical commercial water electrolysis unit ( $51 \mathrm{kWh} / \mathrm{kg} \mathrm{H}_{2}$ at STP).

\subsection{Offshore Storage and Transportation}

For an offshore PtG plant to be feasible, infrastructure must be in place to accommodate storage and transport of the gaseous fuels produced. Where $\mathrm{H}_{2}$ as an end product is concerned, pressure tanks (presently 4-400 bar, with 700 bar storage under development) are usually incorporated, with $88 \%$ of operating onshore PtG plants opting for this form of storage as of 2013 [21]. Although an inherent advantage of high pressure storage is the reduction in required space as storage pressure is increased, the overall system efficiency may drop due to the need for a hydrogen compressor [21]. This poses an interesting question as to whether to situate such containers onshore or on bespoke floating structures offshore. The latter option would require more stringent design criteria associated with the harsher environmental conditions offshore, but these factors may be offset by a decrease in installation time and cost. This leads to a novel idea; there exists a window of opportunity to retrofit abandoned rigs from depleted gas reservoirs, and repurposing them as offshore PtG farms. The gas storage system requirements will be determined by the existing infrastructure available in terms of existing pipe lines ashore, the depleted gas reservoirs, and the level of renewable gas production at a site. 
A second gas storage option is to make use of existing geological formations, as proposed for carbon sequestration [22]. Noting again the possibility of utilising existing infrastructure, the locations of porous rock structures left over from depleted oil and gas fields are obviously well known.

Submerged isobaric energy bags offer another novel approach to offshore gas storage, and are currently being investigated in the context of compressed air energy storage. However, such energy bags are designed to operate in water depths of the order of several hundred metres [23], and so it may not be feasible to co-locate them together with shallower depth fixed and floating foundation offshore wind energy converters.

Logistical and economic issues must be addressed with regard to transporting the end products either by pipeline or by ship to for onward distribution. For pipelines, the inherent installation costs might be avoided by co-locating PtG farms at sites of depleted gas fields where connections to the gas grid are already in place. Under such circumstances, the limiting factor for a power-to-hydrogen $(\mathrm{PtH})$ system would be dictated by the maximum allowable hydrogen concentration in the gas mixture. For example, in Germany, hydrogen is currently limited to 5\% by volume to ensure minimum quality within the grid [12].

The gas product transportation format explored in this study is the use of the existing gas pipe lines to shore connection to the natural gas $(\mathrm{NG})$ grid. Given that the export capacity of the pipe lines is several times larger than the renewable gas peak production, storage on the platforms is not considered in the analysis in this study, see Section 2.1 for further details. An advantage of this particular type of site and gas storage format is the connection to the gas grid which allows 
gaseous products to be dynamically produced and directly exported, avoiding the need for costly on-site $\mathrm{H}_{2}$ storage which was found by Gotz et al. to contribute up to $21 \%$ of capital costs of a PtG plant [27].

\section{Case Study}

The Old Head of Kinsale gas field was selected as a hypothetical location for the offshore PtG concept. This site is nearing the end of its gas production lifespan, and has suitable infrastructure in place for conversion to PtG use. An overview of the scenarios analysed in this paper is given below in Table 1, with a detailed description of the simulation methodologies in Section 2.5. [table 1 here]

\subsection{Site Description}

Figure 1 shows the location of the Kinsale Gas Field in the Celtic Sea, approximately $50 \mathrm{~km}$ south off the coast of Co. Cork, Ireland. The gas field was first discovered in 1971, with several further satellite sites discovered over the next three decades. The gas field is located in a water depth of $90 \mathrm{~m}$, with reservoirs $>900 \mathrm{~m}$ below the seabed. Two production platforms constructed of steel, Alpha and Bravo, were installed in 1977 to facilitate the extraction of natural gas [24]. [figure 1 here] 
A gas storage facility is currently operated by PSE Kinsale Energy Ltd (KEL) at the main site. The facility has a working volume of 230 million standard cubic meters (Mscm) [25], which is equivalent to $2,472 \mathrm{GWh}$, or $\sim 5 \%$ of Ireland's annual gas consumption in 2013/2014. The maximum withdrawal rate is $29.3 \mathrm{GWh} / \mathrm{d}$, and maximum injection rate into the gas grid is 27.6 $\mathrm{GWh} / \mathrm{d}$. As gas production has begun to wind down, KEL has indicated that existing storage operations are not economically viable in the long term without further development. Upgrade of the storage facility to a PtG terminal may therefore be worth consideration, perhaps on a pilot basis. Gas storage operations ceased in 2017 and production is anticipated to completely cease by 2021 with plans for decommissioning shortly afterwards [24, 25].

\subsection{Existing Infrastructure}

The existing two steel platforms could be reconfigured for PtG production, to house either conversion apparatus or else storage containers for gaseous end-products. The Alpha platform has deck dimensions of $53 \times 25 \mathrm{~m}$ and an elevation of $122 \mathrm{~m}$ above the seabed. It is supported by eight $1.56 \mathrm{~m}$ diameter legs, braced by I-beams and raking tubular members [26], the Bravo platform has similar dimensions.

Ireland has a potential total offshore storage capacity of $94,000 \mathrm{Mt}$ of $\mathrm{CO}_{2}$ [22], with the geological formations in the Celtic Sea Basin particularly suitable for gas storage. The depleted gas fields of the Kinsale gas field offer a storage potential of some $330 \mathrm{Mt}$ of $\mathrm{CO}_{2}$ [22]. However, such a venture would have concomitant risks associated with geological storage, in particular containment risks due to the shallow location of the aquifers and the possibility that 
geological seals may have become compromised by pressure depletion exacerbated by the presence of several faults cutting the top of the reservoir.

\subsection{Wind Resource Assessment}

Hourly wind speed data was obtained from the Irish Marine Institute's website (www.marine.ie) and checked for continuity. The data was recorded at one of the Kinsale platforms between 2003 and 2008 at an elevation of $66 \mathrm{~m}$ above mean sea level. The year 2004 was chosen from the measurement archive for subsequent analysis because it has the most complete data series. The chosen year was also considered representative of the average wind climate at the site. Our analysis of longer-term records from the nearby Cork Airport meteorological station indicates that the 2004 mean wind speed was equivalent to $98 \%$ of the long-term mean. Wind speeds were extrapolated to the proposed turbine hub height of $100 \mathrm{~m}$ asl using the log law, assuming neutral atmospheric stability and a constant surface roughness length of $0.001 \mathrm{~m}$ giving an annual average wind speed of $9.4 \mathrm{~m} / \mathrm{s}$.

\subsection{Turbine Selection}

It has recently been estimated using Levelised Cost of Energy (LCOE) calculations that a floating platform can be economically competitive with a fixed structure under optimised conditions [28]. Examples of deep water, floating wind farms include Statoil's Buchan Deep Hywind pilot project (30MW) [29] and Hexicon's cancelled Dounreay Trì project (10MW) [30], both off the Scottish coast. Taking account of the foregoing, we decided to consider a floating 
offshore wind farm comprising of twelve 6MW Siemens D6 turbines individually mounted to Hywind II type floating foundations.

\subsection{Simulation Methodology and PtG Scenarios}

Electricity generation simulations were carried out using MATLAB Simulink R2013b

(Mathworks, USA) using hourly average wind speed values. Three different PtG technology

options are considered for the direct conversion of wind-generated electricity to gas at the

Kinsale site in scenarios 2-4. For each time step, the Simulink model converts wind speed into

electrical power based on prescribed power curves and the number of turbines at the windfarm.

Scenario 1 (OWF) comprises an offshore floating wind farm with new subsea cables ashore, whilst scenarios 2-4 are PtG systems with hydrogen and methane gases being injected into the existing natural gas infrastructure at the site. Scenario 1 provides a reference electricity-only state with which to compare the results of the PtG gas scenarios.

Scenario $2(\mathrm{PtH})$, sees hydrogen gas produced in PEM electrolysers with feed water being supplied by RO of seawater, the hydrogen is injected directly into the existing gas grid on site. In Scenario $3(\mathrm{ECEM}+\mathrm{PEM})$, the ECEM plant produces $\mathrm{CO}_{2}$ and $\mathrm{H}_{2}$ from seawater. The PEM electrolysers are used to generate additional hydrogen, as the $\mathrm{H}_{2}: \mathrm{CO}_{2}$ ratio from ECEM is not sufficient to convert all the available $\mathrm{CO}_{2}$ to methane. Methanation is carried out using a Sabatier reactor, and methane is injected into the gas grid on site.

Finally, Scenario 4 (ECEM $+\mathrm{CO}_{2}$ seq) is similar to Scenario 3, with the omission of the PEM electrolysis and associated RO plant. Methanation is carried out using a Sabatier reactor and 
methane is injected into the natural gas grid. The surplus $\mathrm{CO}_{2}$ generated by the ECEM process is sequestered.

Quantities of electrolyser feed water required and associated energy for pre-treatment of the seawater are calculated at each time step, depending on the power available and the rate of operation of the electrolyser plant in Scenarios $2 \& 3$. The energy required to purify and pump the feed water is deducted from the power available for gas production.

Table 2 outlines the efficiencies of the individual conversion processes. The three PtG scenarios are graphically illustrated in Figures 2(a), (b), (c).

[table 2 here]

[figure 2a here]

[figure $2 \mathrm{~b}$ here]

[figure 2c here]

Capacity and plant sizing parameters were initially set by the space available on the existing platforms. In all cases, the rate of gas production was far less than the capacity limit of the existing gas production infrastructure. Given the dimensions of the existing platforms at the Kinsale site, it is envisaged that 70 shipping containers could be accommodated, corresponding to c. $70 \mathrm{MW}$ of electrolysers, as discussed in Section 1.2 and Section 3 [31]. This space limit fixes the size and rated capacity of all equipment used in Scenarios 1-4. The cost of gas was determined using the formula: 


$$
\text { Gas Cost }=\frac{\sum_{i}\left(C_{i} \times C R F_{i}\right)+O \& M}{\text { Annual Gas Production }}
$$

where $C C_{i}$ and $C R F_{i}$ are the capital cost and capital recovery factor, (component replacement costs are included) and O\&M is the combined annual operation and maintenance cost.

\section{Results}

The mean wind speed at an elevation $100 \mathrm{~m}$ above sea level (asl) is calculated to be $9.4 \mathrm{~ms}^{-1}$, as discussed in section 2.3. The gross turbine capacity factor was $58 \%$, equivalent to 5072 full-load hours per annum. A single Siemens D6 turbine operating under these conditions would generate 30.4 GWh of electricity over a one-year period.

[figure 3 here]

[figure 4 here]

In order to assess the feasibility of the proposed systems, the practical PtG farm deployable at the existing Kinsale Gas Field platforms were considered in detail. A limiting factor with regard to sizing the farm is the number of electrolysers to be housed, with half of each platform being allocated for electrolysis. Here, 1MW electrolysers were selected, each made up of four $250 \mathrm{~kW}$ units housed in a standard shipping container $(6.1 \times 2.44 \times 2.59 \mathrm{~m})$ [31]. Assuming that the platform can be stripped down so that only the deck remains, this permits 35 electrolysers to be housed on each platform, allowing $2 \mathrm{~m}$ spacing between rows. Mobile RO units are situated on each platform, and based upon the Zeppelin model [32] for quantifying spatial requirements. In order to produce up to $12.5 \mathrm{~m}^{3} / \mathrm{hr}$ of desalinated water, 12 pre-treatment units (six on each 
platform) are placed in standard shipping containers, in order to meet the electrolysis requirements of the energy pathways (outlined in Table 3). The remainder of each platform is assumed to have sufficient space left to accommodate the Sabatier reactor, noting that it was not possible to quantify the reactor's spatial dimensions, nor those of the ECEM system used in the third and fourth scenarios. The ECEM unit incorporates RO, and so there are reduced reverse osmosis system requirements for this option when compared to electrolysis. This design leaves unused space on each platform for the PtH option; however, in order to present a fair comparison of the three production options, the farm size is not increased to maximise the use of this leftover space.

Table 3 provides details of the gas production for each of the energy pathways. The overall efficiency of each system is defined as the final energetic value of the gaseous fuel produced as a percentage of the energy output from the wind turbines:

$$
\eta=\sum \frac{\text { Final gaseous fuel energetic value }}{\text { Wind power }} \times 100
$$

[table 3 here]

These production figures are supplemented by costs incurred during the process. An economic analysis was facilitated by the Simulink model, with input parameters listed in Table 4.

[table 4 here]

Wind farm development costs are taken from [33]. Capital costs are extracted from the upper bound of those presented in order to reflect the increased capital investment associated with the 
water depth and distance to shore. A 30\% reduction in total wind farm capital costs was then applied to account for the elimination of cabling and balance of plant requirements for Scenarios $2-4$ [33], where all power will be converted to gaseous fuel on site. Electrolyser costs are estimated from values reported by ITM Power [34]. Costs for the methanation process are based upon a combined electrolyser and methanation cost of $€ 2000 / \mathrm{kW}$. These are consistent with the methanation costs of $€ 300-500 / \mathrm{kW}$ reported in [35]. Estimates of the cost of ECEM units are assumed to be $€ 1.5$ million/MW as per electrolysis unit costings. For the RO cost, the lower bound is determined from figures given by [36], and converted at a rate of $€ 1=\$ 1.105$, so that the proposed system is given an optimistic appraisal of its economic feasibility. Table 5 presents the forecast production costs and end-to-end efficiencies (Equation 2) for each energy pathway.

[table 5 here]

\section{Discussion}

As can be seen from the preceding results, none of the three scenarios produces gas at a cost comparable to present natural gas wholesale market prices $\left(\_0.02 / \mathrm{kWh}[37]\right)$. The $\mathrm{PtH}$ case fares the best, and the costs fall within the range of most of the studies reviewed by [27]. Hydrogen can also be injected directly into the gas grid upon production. When the production and flow of natural gas from the reservoir is discontinued as planned, the PtH scenario would be transporting $100 \%$ hydrogen through the existing steel subsea pipelines raising leakage and hydrogen embrittlement concerns. When injecting the $\mathrm{H}_{2}$ to the onshore $\mathrm{NG}$ grid, the $\mathrm{H}_{2}$ will be 
blended with NG, and blend ratios are currently limited, with a 10\% per volume upper limit advised by [38] and 15\% cited by NREL [39].

The electricity-to-methane pathway incorporating ECEM is the worst from an economic perspective, as might be expected, given that the process is still at a pilot stage of development and the conversion efficiencies are low. For Scenario 4, the excess $\mathrm{CO}_{2}$ produced by the process $(1,748$ tonnes/a) is sequestered and if a carbon cost of $€ 100 /$ tonne is applied the cost of methane production reduces from $\mathrm{c} € 2.20$ to $€ 2.19$ per $\mathrm{kWh}$. Alternative transformation pathways such as power-to-methanol or power-to-ammonia may prove to be more economically attractive, but these may incur additional costs for storage and offloading. If the ECEM process as applied in this study were to proceed to a commercial stage, it is anticipated that the process efficiency would improve from $5.3 \%$ and gas production costs would therefore decrease. The prospect of coupling renewable fuel production with the removal of $\mathrm{CO}_{2}$ from the atmosphere via the oceans would also be attractive from a sustainability perspective. It is obvious that the opportunity to repurpose the existing Kinsale platforms to act as an offshore $\mathrm{PtG}$ farm is not economically feasible at present. This finding may also hold for offshore platforms globally due to the general applicability of present methodology adopted herein. Moreover, the case would have exploited the abundant wind resources available off the southwest coast of Ireland [40].

Our Simulink model was based upon process efficiencies as opposed to experimental results; therefore, it was not possible to examine how sensitive the gas production costs are to wind farm capacity. Additional electrolysers could perhaps be incorporated onto existing platforms through 
stacking of containers, subject to design checks. The carrying capacity of each platform jacket foundation is approximately 4,000 tonnes.

It could also prove useful to compare these projected costs with those involved in decommissioning. Detailed estimates of the latter are not widely available, however based on decommissioning estimates published by [41] of $£ 4,000 / t$ (topside) and $£ 4,500 / t$ (substructure), the c. $8,000 \mathrm{t}$ Kinsale platforms could cost c. $€ 38 \mathrm{~m}$ each to fully decommission (assuming a conversion rate of $1 £=1.14 €)$.

The capital costs associated with methanation equipment remain a source of uncertainty. However, the estimate of $€ 500 / \mathrm{kW}$ capacity used in this study is broadly consistent with other estimates in the literature. For example, Saric et al. [42] estimated a capital cost for methanation of $€ 286 / \mathrm{kW}$ and DNV KEMA's 2013 report estimated current costs at $€ 700 / \mathrm{kW}$ for kW-scale units and suggested that costs would decrease to $€ 300-€ 500 / \mathrm{kW}$ at greater scales [13]. The cost of offshore wind continues to fall. In the UK's September 2017 allocation round for contracts for difference projects, the lowest strike price for offshore wind was $£ 57.50 / \mathrm{MWh}$ (2012 UK prices; £57.50 was approximately $€ 64.00$ as of September 2017) [43]. By examining the long-term feasibility of offshore $\mathrm{PtG}$, it has been suggested that offshore wind capital costs will fall from $\sim € 3$ million/MW in 2012 to $€ 1.2$ million/MW by 2030 [44,45], and that PEM electrolysis might attain efficiencies up to $93 \%$ [13]. Without accounting for any other cost reductions, or decreases in O\&M costs, these improvements would lead to a $40 \%$ reduction in hydrogen gas production costs to $\_0.09 / \mathrm{kWh}$ for the $\mathrm{PtH}$ option. Given that natural gas is a 
fossil fuel, with finite reserves, it is therefore possible that offshore PtG could become a feasible energy source in the future.

\section{Conclusion}

This paper examined the prospect of repurposing existing, offshore gas platforms as power-to-gas farms. The study considered three power to gas options, PtH, PtG and ECEM at a site off the southwest coast of Ireland. It was found that the technology exists for a complete, end-to-end conversion process, entirely transforming renewable electricity from fluctuating sources, such as wind or wave power, to readily stored hydrogen or methane. In the case of ECEM, $\mathrm{CO}_{2}$ is also sequestered from the ocean. Using present-day technology with its attendant costs, the repurposing of gas production platforms does not yet appear to be economically viable, but $\mathrm{PtH}$ technology is far closer market viability than PtG using ECEM. The PtH scenario produced hydrogen at $€ 0.16 / \mathrm{kWh}$, some eight times the wholesale market cost of natural gas, whilst ECEM \& PEM produced methane at $€ 1.53 / \mathrm{kWh}$. This is largely due to the high capital costs of the technology for conversion of electricity to the final gaseous product and, in the case of the ECEM process, low conversion efficiencies. For the most viable option (electricity to hydrogen, PtH) the overall end-to-end efficiency is $\sim 75 \%$. This is comparable to many other utility-scale energy conversion processes (e.g. pumped hydropower round-trip efficiency is typically $80 \%$ [46]). The major disadvantage is simply that electricity is a more valuable energy carrier than gas. However, forecast reductions in the capital cost of offshore wind farms and electrolysers should lower the cost of renewable gas, i.e. hydrogen, to within a factor of five of the cost of natural gas. As conventional natural gas wells decline and land to house renewable generation becomes less 
available, and the potential of gaseous fuels grows within the transport industry, it is possible to envisage a future where offshore power-to-gas systems become a reality.

\section{Acknowledgements}

This research was funded by Science Foundation Ireland (SFI) through the Centre for Marine and Renewable Energy, MaREI (12/RC/2302).

The authors would also like to acknowledge Mike Murray from Kinsale Energy Limited for providing information regarding the platforms, and the Irish Marine Institute for providing offshore wind speed data. 


\section{References}

[1] Twomey B. Overview of Global Decommissioning. In: 5th Annual Seminar on Enhancing Public Petroleum Management. Bangkok,12 - 14 June 2012.

[2] Wan Abdullah Zawawi NA, Liew MS and Na KL. Decommissioning of offshore platform: A sustainable framework, in: CHUSER 2012 - 2012 IEEE Colloq. Humanit. Sci. Eng. Res., 3-4 December 2012: pp. 26-31. doi:10.1109/CHUSER.2012.6504275.

[3] European Parliament and Council, Directive 2008/98/EC of the European Parliament and of the Council of 19 November 2008 on waste and repealing certain directives. Off. J. Eur. Union. 32008;34: 3-30.

[4] Kaiser MJ and Liu M, Decommissioning cost estimation in the deepwater U.S. Gulf of Mexico - Fixed platforms and compliant towers, Mar. Struct. 2014; 37: 1-32. doi:10.1016/j.marstruc.2014.02.004.

[5] Intergovernmental Panel on Climate Change. Summary for Policymakers Climate Change 2013 - The Physical Science Basis: Working Group I Contribution to the Fifth Assessment Report of the Intergovernmental Panel on Climate Change. Cambridge: Cambridge University Press, 2014, 1-30

[6] Lackner KS, Brennan S, Matter JM, Alissa Park A-H, Wright A and Van Der Zwaan B. The urgency of the development of $\mathrm{CO}_{2}$ capture from ambient air. Proc. Natl. Acad. Sci. 2012;109: 13156-13162. doi:10.1073/pnas.1108765109. 
[7] Doney SC, Fabry VJ, Feely RA and Kleypas JA. Ocean Acidification: The Other $\mathrm{CO}_{2}$ Problem. Ann. Rev. Mar. Sci. 2009;1: 169-192. doi:10.1146/annurev.marine.010908.163834.

[8] Martin Almenta M, Morrow D, Best R, Fox B and Foley A. An analysis of wind curtailment and constraint at a nodal level. IEEE Transactions on Sustainable Energy 2016; 8(2): 488495. doi: 10.1109/TSTE.2016.2607799

[9] Mc Garrigle E, Deane JP and Leahy P. How much wind energy will be curtailed on the 2020 Irish electrical system? Renewable Energy 2013;55: 544-553. doi:10.1016/j.renene.2013.01.013

[10] Vo TT, Xia A, Wall DM and Murphy JD. Use of surplus wind electricity in Ireland to produce compressed renewable gaseous transport fuel through biological power to gas systems. Renewable Energy 2017;105, 495-504. doi:10.1016/j.renene.2016.12.084

[11] Bennaceur K, Clark B, Orr FM, Ramakrishnan TS, Roulet C and Stout E. Hydrogen : A Future Energy Carrier?, Oilf. Rev. Spring 2005, 30-41.

[12] Schiebahn S, Grube T, Robinius M, Tietze V, Kumar B and Stolten D, Power to gas: Technological overview, systems analysis and economic assessment for a case study in Germany. Int. J. Hydrogen Energy 2015;40: 4285-4294. doi:10.1016/j.ijhydene.2015.01.123.

[13] Grond L, Schulze P, and Holstein J. Systems Analyses Power-to-Gas: A Technology Review. Tech. Rep., DNV KEMA Energy \& Sustainability, http://www.europeanpowertogas.com/fm/download/28 (2013, accessed September 2017). 
[14] Water Electrolysis \& Renewable Energy Systems, Fuel Cell Today, http://www.fuelcelltoday.com/media/1871508/water_electrolysis__renewable_energy_syst ems.pdf, (2013, accessed September 2017).

[15] Maria Grünauer K. ETOGAS Company Presentation, https://www.slideshare.net/DrKarlMariaGrnauer/etogascompanypresentation-dr-karl-mariagrnauer (2015, accessed November 2017).

[16] Meier K. Hydrogen production with sea water electrolysis using Norwegian offshore wind energy potentials, Int. J. Energy Environ. Eng. 2014;5: 1-12. doi:10.1007/s40095-014-01046.

[17] Elimelech M and Phillip WA. The Future of Seawater and the Environment: Energy, Technology, and the Environment. Science 2011;333: 712-718. doi:10.1126/science.1200488.

[18] Greenlee LF, Lawler DF, Freeman BD, Marrot B, and Moulin P. Reverse osmosis desalination: Water sources, technology, and today's challenges, Water Res. 2009;43: 23172348. doi:10.1016/j.watres.2009.03.010.

[19] Willauer HD, Dimascio F, Hardy DR and Williams FW. Feasibility of CO2 Extraction from Seawater and Simultaneous Hydrogen Gas Generation Using a Novel and Robust Electrolytic Cation Exchange Module Based on Continuous Electrodeionization Technology, Ind. Eng. Chem. Res. 2014: 12192-12200.

[20] Eisaman MD, Parajuly K, Tuganov A, Eldershaw C, Chang N and Littau KA. CO2 extraction from seawater using bipolar membrane electrodialysis, Energy Environ. Sci. 2012; 5: 7346 - 7352. doi:10.1039/c2ee03393c. 
[21] Gahleitner G. Hydrogen from renewable electricity: An international review of power-to-gas pilot plants for stationary applications, Int. J. Hydrogen Energy 2013;38: 2039-2061. doi:10.1016/j.ijhydene.2012.12.010.

[22] Lewis D, Bentham M, Cleary T, Vernon R, O’Neill N, Kirk K, Chadwick A, Hilditch D, Michael K, Allinson G, Neal P and Ho M. Assessment of the potential for geological storage of carbon dioxide in Ireland and Northern Ireland, Energy Procedia 2009; 1: 2655-2662. doi:10.1016/j.egypro.2009.02.033.

[23] Vasel-Be-Hagh AR, Carriveau R and Ting DSK. Flow over submerged energy storage balloons in closely and widely spaced floral configurations, Ocean Eng. 2015; 95: 59-77. doi:10.1016/j.oceaneng.2014.11.030.

[24] PSE Kinsale Energy Limited company website: http://www.kinsale-energy.ie/history.html \& https://www.kinsale-energy.ie/gas-storage.html (2018, accessed 03 July 2018).

[25] Network Development Plan 2016 Assessing Future Demand and Supply Position. Tech. Report, Gas Networks Ireland, Cork, Ireland. https://www.gasnetworks.ie/corporate/company/our-network/network-developmentplan/GNI_NetworkDevPlan_2016-(1).pdf, (2016, accessed 14 November 2017).

[26] Hartnett M, Mullarkey T and Keane G. Modal Analysis of an existing Offshore Platform, Eng. Struct. 1997; 19(6): 487-498.

[27] Götz M, Lefebvre J, Mörs F, Koch AM, Graf F, Bajohr, S, Reimert, R and Kolb T. Renewable Power-to-Gas: A technological and economic review, Renewable Energy 2016; 85: $1371-1390$ 
[28] Myhr A, Bjerkseter C, Ågotnes A and Nygaard TA. Levelised cost of energy for offshore floating wind turbines in a life cycle perspective, Renewable Energy 2014; 66: 714-728. doi:10.1016/j.renene.2014.01.017.

[29] Statoil ASA. Hywind Scotland. https://ukenergy.statoil.com/wind (2018, accessed 03rd September 2018).

[30] Hexicon AB. Dounreay Trì Powered By Hexicon. https://www.hexicon.eu/dounreay-tri/ (2018, accessed 03rd July 2018).

[31] Proton On Site. Technical Specifications, M Series Hydrogen Generation System, http://www.protononsite.com/sites/default/files/2017-04/PD-0600-0119\%20REV\%20A.pdf, (2017, accessed 14th November 2017).

[32] Zeppelin Mobile Systems. ZEPPELIN Mobile Containerized Sea Water Desalination Plant, http://www.zeppelin-mobile.de/wasser01e.htm (2017, accessed November 14th 2017).

[33] International Energy Agency Energy Technology Systems Analysis Programme and International Renewable Energy Agency. Wind power - Technology Brief 2016, http://www.irena.org/DocumentDownloads/Publications/IRENAETSAP_Tech_Brief_Wind_Power_E07.pdf, (2017, accessed 14 November 2017)

[34] ITM Power. 1.5 MW Electrolyser Deployment in Scotland, http:/www.itmpower.com/news-item/1-5-mw-electrolyser-deployment-in-scotland (2016, accessed July 25, 2016).

[35] Lehner M, Tichler, Steinmuller RH and Koppe HM. Power-to-Gas: Technology and Business Models. Springer International, 2014, pp. 41-60 
[36] Ghaffour N, Missimer TM and Amy GL. Technical review and evaluation of the economics of water desalination: Current and future challenges for better water supply sustainability, Desalination 2013; 309: 197-207. doi:10.1016/j.desal.2012.10.015.

[37] European Commission Directorate-General for Energy. Quarterly Report on European Gas Markets (first quarter of 2017), 2017; 10(1).

[38] Altfeld K and Pinchbeck D. Admissible hydrogen concentrations in natural gas systems, Gas for Energy, 2013; 3. ISSN 2192-158X. www.europeanpowertogas.com/fm/download/4, (2013, accessed 26th September 2017)

[39] Meina MW, Antonia O and Penev M. Blending Hydrogen into Natural Gas Pipeline Networks: A Review of Key Issues. Technical Report, National Renewable Energy Laboratory USA. Report no. NREL/TP-5600-51995, March 2013.

[40] Troen I and Lundtang Petersen E. European Wind Atlas, 1989. Report, Risoe National Laboratory, 1989. Roskilde, Denmark.

[41] Oil \& Gas UK. Decommissioning Insight 2015. Report, Oil \& Gas UK, Aberdeen, UK. http://oilandgasuk.co.uk/wp-content/uploads/2015/11/Decommissioning-Insight-2015updated.pdf (accessed 14 November 2017)

[42] Saric M, Dijkstra JW and Haije WG. Economic perspectives of Power-to-Gas technologies in bio-methane production, Journal of $\mathrm{CO}_{2}$ Utilization 2017; 20: 81-90

[43] HM Government - Department for Business, Energy \& Industrial Strategy. Contracts for Difference Second Allocation Round Results, https://www.gov.uk/government/uploads/system/uploads/attachment_data/file/643560/CFD _allocation_round_2_outcome_FINAL.pdf, September 2017. (2017, accessed 14 November 2017) 
[44] Higgins P and Foley A. The evolution of offshore wind power in the United Kingdom. Renewable and Sustainable Energy Reviews 2014;37: 599 - 612

[45] Green R. and Vasilakos N. The economics of offshore wind. Energy Policy 2011; 39: 496502 doi: $10.1016 /$ j.enpol.2010.10.011

[46] Bogenrieder W. Pumped Storage Plants. In: Renewable Energy, Springer Berlin Heidelberg, 2006 (3C), pp. 165-196 


\begin{tabular}{|c|c|}
\hline Scenario & Description \\
\hline $1 \mathrm{OWF}$ & Offshore floating wind farm, power brought ashore using new subsea cabling. \\
\hline 2 PtH & $\begin{array}{l}\text { Wind farm powers hydrogen production and injection into existing natural gas } \\
\text { grid. The PEMEC feed water is derived from RO and deionisation of seawater. } \mathrm{H}_{2} \\
\text { is injected into the gas grid }\end{array}$ \\
\hline 3 ECEM + PEM & $\begin{array}{l}\text { Wind farm powers ECEM, PEMEC, methanation and gas injection processes. } \\
\text { ECEM produces } \mathrm{CO}_{2} \text { and } \mathrm{H}_{2} \text { from seawater. PEMECs generate additional } \mathrm{H}_{2} \text { to } \\
\text { make up deficit. Methanation by Sabatier reactor, } \mathrm{CH}_{4} \text { is injected into the gas grid }\end{array}$ \\
\hline $\begin{array}{c}\text { 4. } \mathrm{ECEM}+\mathrm{CO}_{2} \\
\text { seq }\end{array}$ & $\begin{array}{l}\text { Similar to Scenario 3, with omission of PEMECs and associated RO plant. } \\
\text { Methanation by Sabatier reactor and } \mathrm{CH}_{4} \text { is injected into the gas grid. The } \\
\text { surplus } \mathrm{CO}_{2} \text { generated by ECEM is sequestered. }\end{array}$ \\
\hline
\end{tabular}



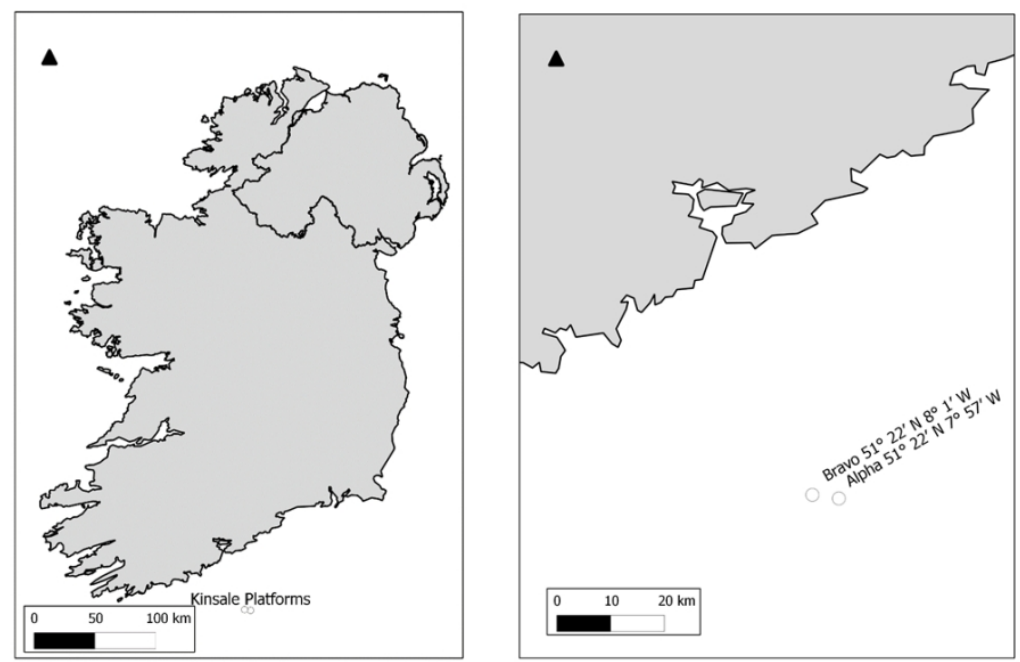

Figure 1: Location of Kinsale Gas Field and platforms 


\begin{tabular}{|c|c|}
\hline Wind farm & $72 \mathrm{MW}(12 \times$ Siemens D6) efficiency as per D6 power curve \\
\hline $\begin{array}{l}\text { Water } \\
\text { purification } \\
\text { plant }\end{array}$ & $\begin{array}{l}\text { RO plant based on a peak water production requirement when the wind farm is at full } \\
\text { capacity and the electrolyser and ECEM are also operating full capacity, with secondary } \\
\text { treatment from a deionisation (DI) plant to produce ASTM Type II water }\end{array}$ \\
\hline Electrolyser & $\begin{array}{l}75 \% \text { simple conversion efficiency for PEM electrolyser with plant sizing to match rated } \\
\text { wind farm capacity for Scenario } 2 \\
\text { Plant sizing } 4.4 \% \text { of wind farm capacity to make up shortfall in hydrogen production from } \\
\text { ECEM for ratio of } 1 \mathrm{CO}_{2}: 4 \mathrm{H}_{2} \text { molecules at methanation reactor for Scenario } 3\end{array}$ \\
\hline $\begin{array}{c}\text { ECEM } \\
\text { (Scenario 3) }\end{array}$ & $\begin{array}{l}\text { Energy requirement from [17] } 49 \mathrm{kWh} / \mathrm{m}^{3} \mathrm{H}_{2} \text { and a plant sizing of } 95.6 \% \text { wind farm } \\
\text { capacity for Scenario } 3 \text { and } 100 \% \text { for Scenario } 4\end{array}$ \\
\hline $\begin{array}{l}\text { Methanation } \\
\text { (Scenarios } \\
3 \text { and 4) }\end{array}$ & $\begin{array}{l}78 \% \text { simple conversion efficiency Sabatier reaction, plant sizing of } 75 \% \text { of the } 72 \mathrm{MW} \\
\text { wind farm to match peak hydrogen gas production from electrolysis and ECEM plant for } \\
\text { Scenarios } 3 \text { and } 4\end{array}$ \\
\hline
\end{tabular}




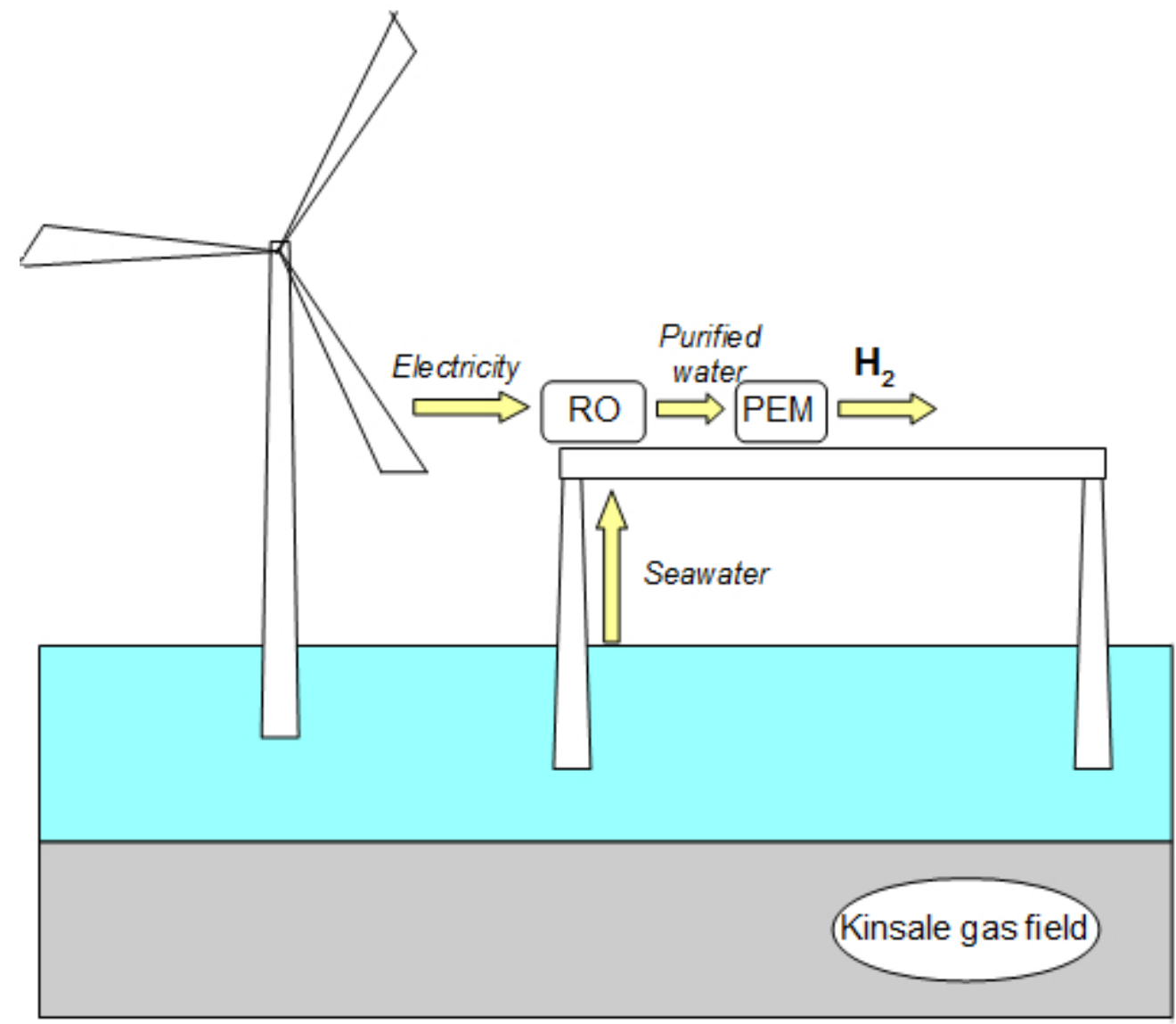

Figure 2(a): Scenario 2, Power-to-Hydrogen 


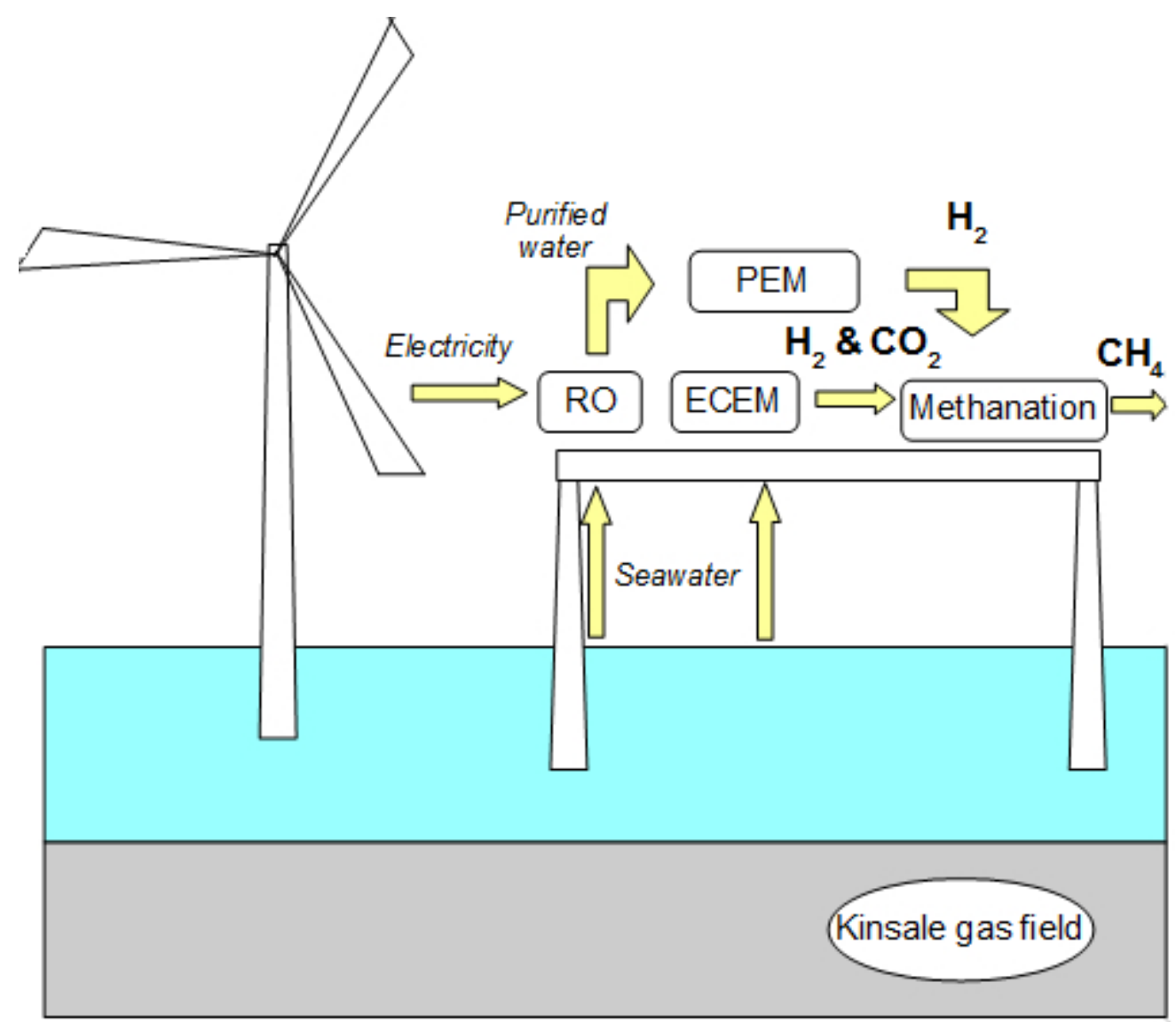

Figure 2(b): Scenario 3, Power-to-Gas using ECEM with additional PEM electrolysis 


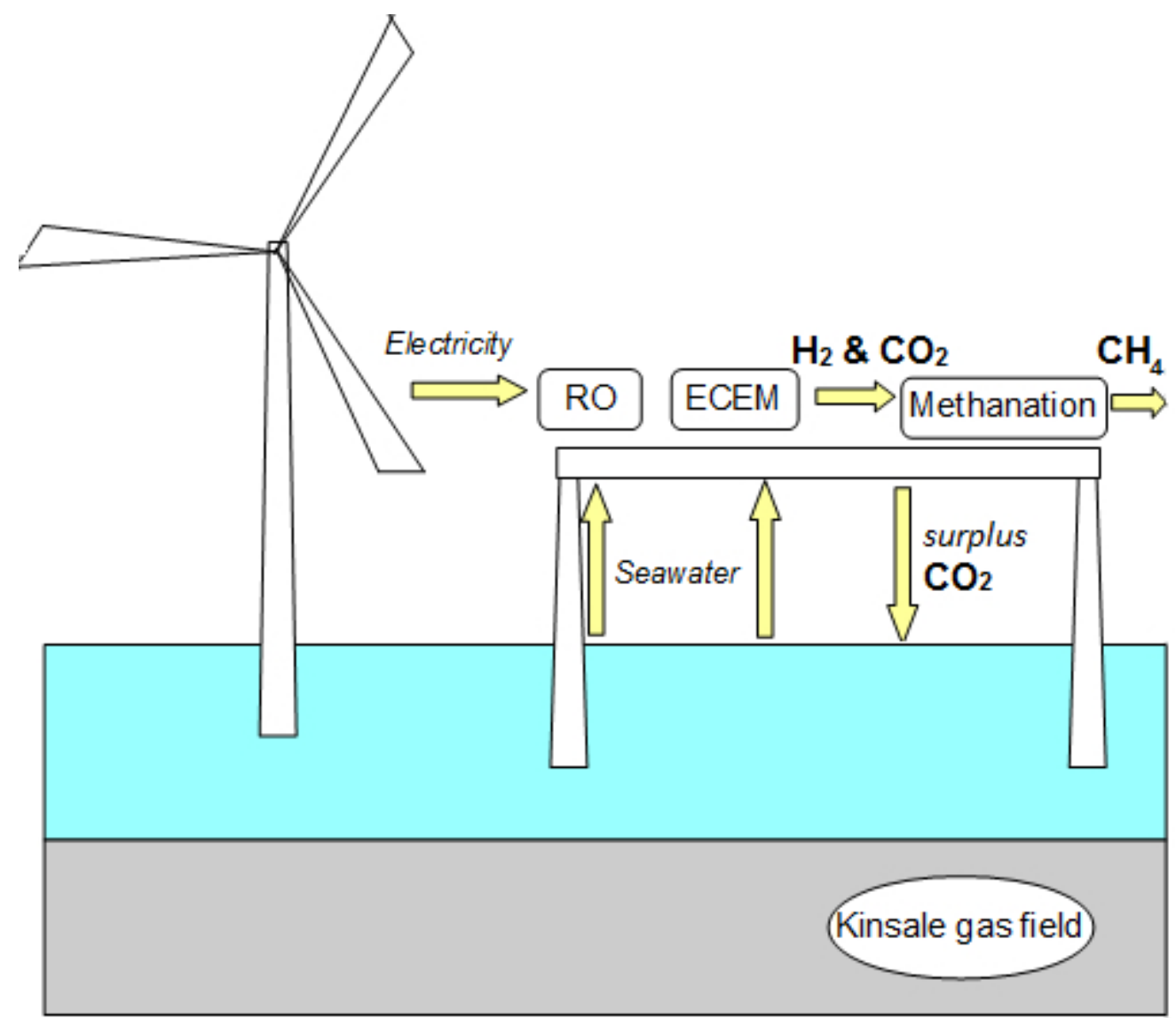

Figure 2(c): Scenario 4, Power-to-Gas ECEM with surplus CO2 sequestration 

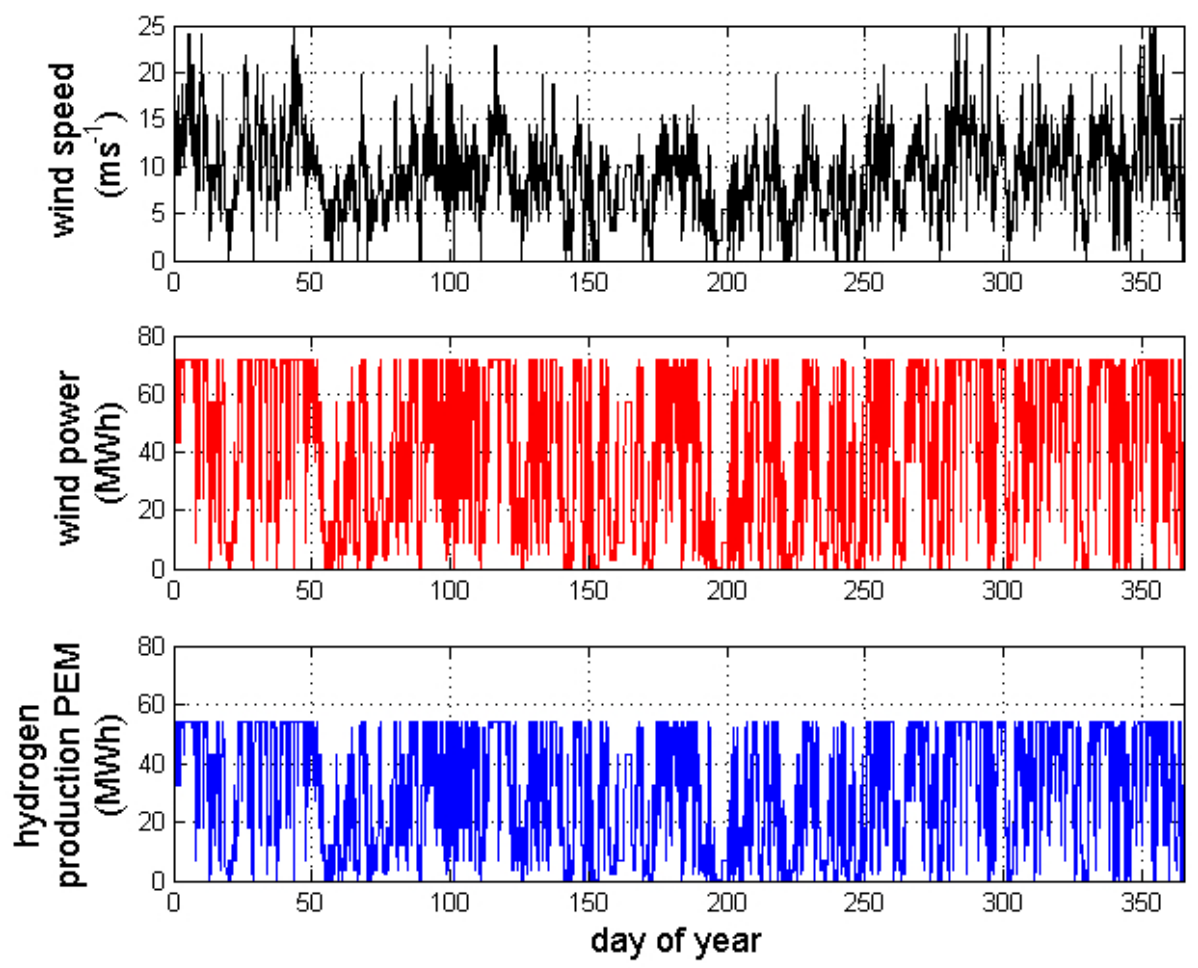

Figure 3: Scenario 2, wind speed, wind power and hydrogen production over a one-year period 

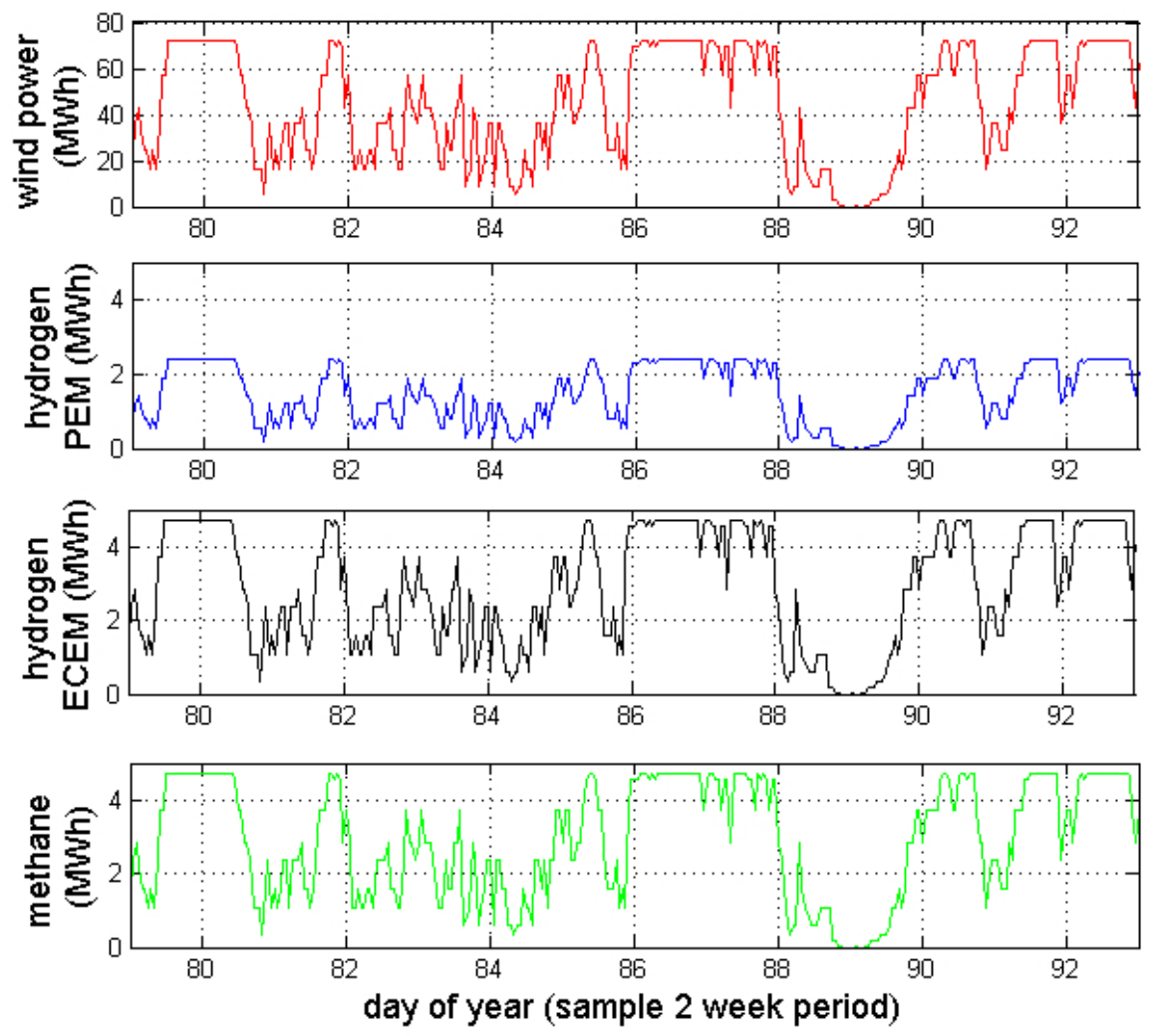

Figure 4: Scenario 3, wind power, hydrogen production from electrolyser, hydrogen production from ECEM and methane production for a sample two-week period 


\begin{tabular}{|c|c|c|c|}
\hline & $\begin{array}{c}\text { Scenario } 2 \\
\text { PtH } \\
\left(\mathrm{H}_{2}\right)\end{array}$ & $\begin{array}{c}\text { Scenario } 3 \\
\text { ECEM+PEM } \\
\left(\mathrm{CH}_{4}\right)\end{array}$ & $\begin{array}{c}\text { Scenario } 4 \\
\text { ECEM+Seq } \\
\left(\mathrm{CH}_{4}\right)\end{array}$ \\
\hline Seawater feed to RO plant peak $\left(\mathrm{m}^{3} / \mathrm{h}\right)$ & 27.18 & 1.22 & na \\
\hline Seawater feed to ECEM plant peak $\left(\mathrm{m}^{3} / \mathrm{h}\right)$ & na & 18,100 & 18,960 \\
\hline RO peak output to electrolyser $\left(\mathrm{m}^{3} / \mathrm{h}\right)$ & 12.23 & 0.55 & na \\
\hline Gas grid blend hydrogen blend (\%) & 14.57 & na & na \\
\hline Gas production peak $(\mathrm{MWh} / \mathrm{h})$ & 53.88 & 5.54 & 3.85 \\
\hline Gas production per year (GWh/a) & 272.85 & 28.04 & 19.49 \\
\hline Surplus $\mathrm{CO}_{2}$ sequestered (tonnes/a) & na & na & 1,750 \\
\hline
\end{tabular}




\begin{tabular}{|lc|}
\hline Discount rate & $5 \%$ \\
\hline Windfarm capital cost (€/MW) & $3,150,000$ \\
\hline Windfarm O\&M (c€/kWh) & 2.5 \\
\hline Electrolyser capital cost $(€ / \mathrm{MW})$ & $1,500,000$ \\
\hline Electrolyser O\&M $(\%$ capital cost/a) & $5 \%$ \\
\hline Electrolyser membranes, 10 year replacement $(€ / \mathrm{MW})$ & 150,000 \\
\hline RO capital cost $\left(€ / \mathrm{m}^{3} /\right.$ day) & 814.34 \\
\hline RO desalination cost $\left(€ / \mathrm{m}^{3} /\right.$ day) & 0.45 \\
\hline Methanation capital cost $(€ / M W)$ & 500,000 \\
\hline Methanation O\&M $(\%$ capital cost/a) & $5 \%$ \\
\hline Methanation components, 10 year replacement $(€ / M W)$ & $5 \%, 000$ \\
\hline ECEM capital cost $(€ / M W)$ & $1,500,000$ \\
\hline ECEM O\&M $(\%$ capital cost/a) & 50,000 \\
\hline
\end{tabular}




\begin{tabular}{|c|c|c|c|c|}
\hline & $\begin{array}{c}\text { Scenario } 1 \\
\text { OWF } \\
\text { (electricity) }\end{array}$ & $\begin{array}{c}\text { Scenario } 2 \\
\text { PtH } \\
\left(\mathrm{H}_{2}\right)\end{array}$ & $\begin{array}{c}\text { Scenario } 3 \\
\text { ECEM + PEM } \\
\left(\mathrm{CH}_{4}\right)\end{array}$ & $\begin{array}{c}\text { Scenario } 4 \\
\text { ECEM } \\
\left(\mathrm{CH}_{4}\right)\end{array}$ \\
\hline Electricity production cost ( $€ / \mathrm{MWh})$ & $\begin{array}{c}105.2(\mathrm{AC}) \\
104.2(\mathrm{HVDC})\end{array}$ & na & na & na \\
\hline Gas production cost (c€/kWh) & na & 15.7 & 153.2 & 219.5 \\
\hline Overall PtG efficiency $\boldsymbol{\eta}(\%)$ & na & 74.8 & 7.7 & 5.3 \\
\hline Total system costs $(€ \mathrm{~m})$ & 325.68 & 335.1 & 334.8 & 334.8 \\
\hline
\end{tabular}

